\title{
PREDICTION OF MEAT PRODUCT QUALITY BY THE MATHEMATICAL PROGRAMMING METHODS
}

\section{ПРОГНОЗИРОВАНИЕ КАЧЕСТВА МЯСНЫХ ИЗДЕЛИЙ МЕТОДАМИ МАТЕМАТИЧЕСКОГО ПРОГРАММИРОВАНИЯ}

Lisitsyn A.B., Nikitina M.A., Zakharov A.N., Sus E.B., Nasonova V.V., Lebedeva L.I. The V.M. Gorbatov All-Russian Meat Research Institute, Moscow, Russia

\begin{abstract}
Ключевые слова: информационные технологии, прогнозирование, комплексный критерий качества, физикохимические и функиионально технологические показатели
\end{abstract}

\begin{abstract}
Аннотация
Применение прогнозных технологий является одним из направлений научно-исследовательских работ, проводимых как в России, так и за рубежом. Переработка мяса сопровождается сложными физико-химическими, биохимическими и механическими прочессами. Для прогноза поведения мясного сырья в ходе технологической обработки используют комплекс функиионально-технологических и структурно-механических показателей, объективно отражающих его качество (величина $р$, водосвязывающая и жироудерживающая способности, активность воды, липкость, вязкость, пластичность и т.д.). В статье показано влияние животных белков (говяжьих и свиных) на физико-химические и функииональные свойства мясных фартей до и после термической обработки, выработанных из мясного сырья с разным содержанием соединительной и жировой тканей. На основе опытных данных с помощььо методов регрессионного анализа были получены параметры модели (стохастической зависимости), связывающие количественные результируюшие и факторные переменные, и оценена степень согласованности с экспериментальными данными. Методами математического программирования были установлены предельно допустимые уровни замены мясного сырья животными белками (говяжьими и свиными). Применение инбормационных технологий существенно сократит затраты на экспериментальный поиск и обоснование оптимального уровня замены мясного сырья животными белками (говяжьими, свиными), а также поможет установить взаимосвязь показателей качества продукта с количеством и качеством ингредиентов в мясном фарше.
\end{abstract}

\section{Введение}

Одно из направлений государственной политики в области здорового питания является разработка высококачественных пищевых продуктов с заданным химическим составом и пищевой ценностью, отвечающих всем требованиям технических регламентов и нормативных документов. В связи с этим важнейшей задачей мясоперерабатывающей промышленности является рациональное использование сырья, интенсификация производства на основе использования научно-технического прогресса и внедрения прогрессивных технологий, расширение ассортиментного ряда продукции и повышение качества продукции, в том числе за счет создания новых видов продуктов на основе сочетания мясного сырья с белками животного и растительного происхождения.

Концепция моделирования и оптимизации, сформулированная в трудах школы академика Кафарова В.В. [1],
Keywords: information technologies, prediction, complex quality criterion, physico-chemical and functional technological indicators

\section{Abstract}

Use of the prediction technologies is one of the directions of the research work carried out both in Russia and abroad. Meat processing is accompanied by the complex physico-chemical, biochemical and mechanical processes. To predict the behavior of meat raw material during the technological processing, a complex of physico-technological and structural-mechanical indicators, which objectively reflects its quality, is used. Among these indicators are $\mathrm{pH}$ value, water binding and fat holding capacities, water activity, adhesiveness, viscosity, plasticity and so on. The paper demonstrates the influence of animal proteins (beef and pork) on the physico-chemical and functional properties before and after thermal treatment of minced meat made from meat raw material with different content of the connective and fat tissues. On the basis of the experimental data, the model (stochastic dependence) parameters linking the quantitative resultant and factor variables were obtained using the regression analysis, and the degree of the correlation with the experimental data was assessed. The maximum allowable levels of meat raw material replacement with animal proteins (beef and pork) were established by the methods of mathematical programming. Use of the information technologies will significantly reduce the costs of the experimental search and substantiation of the optimal level of replacement of meat raw material with animal proteins (beef, pork), and will also allow establishing a relationship of product quality indicators with quantity and quality of minced meat ingredients.

\section{Introduction}

One of the directions of the state policy in the field of health nutrition is the development of high quality food products with the targeted chemical composition and food value that correspond to all requirements of the technical regulations and normative documentations. In this connection, an important task of the meat processing industry is the rational use of raw material, intensification of production on the basis of using the scientifictechnical progress and incorporation of the progressive technologies, extension of the product assortment and increase in product quality through, among other things, the development of new types of products based on the combination of meat raw material with animal and plant proteins.

The concept of modeling and optimization, which is stated in the works of the school of academician Kafarov V.V. [1], is associated with predicting quality of 
связана с прогнозированием качества продукции переработки биосырья животного происхождения со случайными характеристиками и свойствами.

Начальная неопределенность обусловлена разбросом показателей и свойств сырья биологического происхождения (физико-химических и функционально-технологических показателей) может быть охарактеризована величиной энтропии [2-3]:

$$
H\left(\Delta z_{x}\right)=-\sum_{j=1}^{\mu} \sum_{k=1}^{\chi} \sum_{r=1}^{R} P\left(\Delta z_{x}^{j k r}\right) \log _{2} P\left(\Delta z_{x}^{j k r}\right)
$$

где $\left(P \Delta z_{x}^{j k r}\right)$ - вероятность $r$-го уровня отклонения $k$-го показателя в $j$-м виде биологического сырья;

и определяет сложность принятия решений с целью обеспечения качества продукции по критериям пищевой и биологической ценности.

Основная задача мясоперерабатывающего предприятия - выработка мясных изделий заданного качества. В связи с этим целевая функция управления качеством может быть представлена в виде иерархии некоторых параметров и показателей, отражающих динамику формирования качества производимых мясных продуктов

$$
Q=\sum_{i=1}^{n} a_{i} \sum_{j=1}^{m_{i}} b_{i j} \ldots \sum_{k=1}^{K_{i j}} d_{i j \ldots k} \Delta x_{i j \ldots k}^{*},
$$

где $a_{i}, b_{i j}, d_{i j . . k}$ - коэффициенты значимости физико-химических, функционально-технологических, сенсорных показателей и структурно-механических свойств, характеризующих качество мясной продукции, определяемые методом экспертных оценок и регрессионного анализа;

$\Delta x_{i j . . . k}^{*}$ - нормативная величина отклонения $\mathrm{k}$-го показателя некоторой группы.

Для сопоставимого анализа влияния различных физико-химических факторов на качество продукции нормированные величины отклонений параметров от заданных значений рассчитывается следующим образом

$$
\Delta x_{i j \ldots k}^{*}=\left|\frac{x_{i j \ldots k}^{0}-x_{i j . . k}}{\Delta x_{i j . . k}^{0}}\right|
$$

где $x_{i j . . k}^{0}, x_{i j . . k}$ - заданное и текущее значение k-го показателя, j-й группы факторов і-го мясного продукта;

$\Delta x_{i j . . k}^{0}$ - допустимое отклонение параметров от заданного значения.

Качество мясного продукта наиболее полно характеризует комплексный критерий качества, учитывающий физико-химические, функционально-технологические показатели и структурно-механические свойства. Особое значение имеют реологические характеристики, коррелирующие с физико-химическими показателями биосырья животного происхождения, мясного фарша и готового изделия [4-5].

Целью данной работы являлось изучение влияния животных белков (говяжьих и свиных) на физико-химические и функциональные свойства products from processing of animal biological material with random characteristics and properties.

The initial uncertainty is conditioned by the dispersion of indicators and properties of biological raw material (the physico-chemical and functional-technological indicators), can be characterized by the entropy value [2-3]:

$$
H\left(\Delta z_{x}\right)=-\sum_{j=1}^{\mu} \sum_{k=1}^{\chi} \sum_{r=1}^{R} P\left(\Delta z_{x}^{j k r}\right) \log _{2} P\left(\Delta z_{x}^{j k r}\right)
$$

where $\left(P \Delta z_{x}^{j k r}\right)$ - probability of the $r^{\text {th }}$ value of deviation of the $k^{\text {th }}$ indicator in the $j^{\text {th }}$ kind of the biological raw material;

and determines the complexity of decision making with the aim of ensuring product quality by the criteria of food and biological value.

The main goal of a meat processing enterprise is to produce meat products with specified quality. In this connection, the target function of quality management can be presented in a form of hierarchy of several parameters and indicators reflecting a dynamics of quality formation in produced meat products:

$$
Q=\sum_{i=1}^{n} a_{i} \sum_{j=1}^{m_{i}} b_{i j} \ldots \sum_{k=1}^{K_{i j}} d_{i j \ldots k} \Delta x_{i j \ldots k}^{*}
$$

where $a_{i}, b_{i j}, d_{i j . k}$ - coefficients of significance of physico-chemical, functional-technological, sensory indicators and structural-mechanical properties characterizing meat product quality, which is determined by the method of expert assessment and regression analysis;

$\Delta x_{i j \ldots k}^{*}$ - normative value of the $k^{\text {th }}$ indicator of some group.

For comparative analysis of an effect of different physico-chemical factors on product quality, the normative values of parameter deviations from the specified values are calculated as follows

$$
\Delta x_{i j \ldots k}^{*}=\left|\frac{x_{i j \ldots k}^{0}-x_{i j . . k}}{\Delta x_{i j . . k}^{0}}\right|
$$

where $x_{i j . . k}^{0}, x_{i j \ldots k}$ - specified and current values of the $k^{\text {th }}$ indicator in the $j^{\text {th }}$ factor group of the $i^{\text {th }}$ meat product;

$\Delta x_{i j . . k}^{0}$ - allowable variation of parameters of the specified value.

A complex quality criterion, which takes into consideration the physico-chemical, functional-technological indicators and structural-mechanical properties, most fully characterizes meat product quality. The rheological characteristics correlating with the physico-chemical indicators of biological raw material of animal origin, minced meat and finished products are of special importance [4-5].

The aim of this work was to study the influence of animal proteins (beef and pork) on the physico-chemical and functional properties of minced meat and cooked samples produced from meat raw material with different content of the connective and fat tissues and to develop a mathematical model for predicting meat product quality dependent on a percentage of meat raw material substitution.

According to the set goal, the following objectives were achieved:

- to determine the content of total and connective tissue 
сырых и вареных мясных фаршей, выработанных из мясного сырья с разным содержанием соединительной и жировой тканей и разработка математической модели прогнозирования качества полученной продукции в зависимости от процента замены мясного сырья.

В соответствии с поставленной целью решались следующие задачи:

- определить содержание общего и соединительнотканных белков, в зависимости от содержания жировой и соединительной тканей в образцах;

- изучить влияние животных белков (свиных и говяжьих) на физико-химические и функционально-технологические показатели ( $\mathrm{pH}$, массовую долю белка, жира, влаги, оксипролина, цвет, активность воды, вязкость, влагосвязывающую способность) на модельных образцах сырого мясного фарша;

- изучить влияние животных белков (свиных и говяжьих) на физико-химические и функционально-технологические показатели ( $\mathrm{HH}$, массовую долю белка, оксипролина, влагоудерживающую способность) на модельных образцах термообработанного мясного фарша;

- разработать математическую модель прогнозирования качества мясного продукта при замене мясного сырья животными белками;

- апробировать разработанную модель.

\section{Материалы и методы}

За модельные образцы мясного фарша были взяты образцы с различным уровнем замены мясного сырья на гидратированные белки животного происхождения в диапазоне от $10 \%$ до $30 \%$ с приращением 10\%. Гидратацию животных белков проводили в соотношении белок : вода для говяжьего - $1: 10$, для свиного - $1: 8$.

В качестве контроля были изготовлены образцы из мяса говядины и свинины полужирной: контроль 1 - говядина жилованная высшего сорта с массовой долей соединительной и жировой тканей не более $3 \%$, контроль 2 - говядина жилованная 2 сорта с массовой долей соединительной и жировой тканей не более $20 \%$, контроль 3 - свинина жилованная полужирная с массовой долей жировой и соединительной тканей не более $45 \%$. В опытные образцы вносили гидратированный животный белок в количестве 10, 20 и 30\% к массе мясного сырья. Поваренную соль во все образцы вносили в количестве $2,2 \%$, также, исходя из функционально-технологических характеристик мясного сырья, во все образцы дополнительно вносили воду, в контрольные образцы в количестве $25 \%$, в опытные образцы исходя из снижения массовой доли мясного сырья. Жилованное мясное сырье с заданным содержанием жировой и соединительной тканей измельчали на волчке с диаметром отверстий решетки 2-6 мм. Затем измельченное мясное сырьё перемешивали в мешалке с поваренной солью, водой с температурой не выше $4{ }^{\circ} \mathrm{C}$ и предварительно гидратированным животным белком до равномерного распределения всех ингредиентов. Каждый из полученных образцов делили на 2 части: одну часть отправляли на проведение запланированных исследований, вторую-формовали proteins in dependence of the content of fat and connective tissues in the samples;

- to study the effect of animal proteins (pork and beef) on the physico-chemical and functional-technological indicators $(\mathrm{pH}$, mass fraction of protein, fat, moisture, oxyproline; color, water activity, viscosity, moisture binding capacity) on the model samples of raw minced meat;

- to study the effect of animal proteins (pork and beef) on the physico-chemical and functional-technological indicators $(\mathrm{pH}$, mass fraction of protein, oxyproline; moisture holding capacity) on the model samples of cooked minced meat;

- to develop a mathematical model for predicting meat product quality upon meat raw material replacement with animal proteins;

- to test the developed model.

\section{Materials and methods}

The samples of minced meat with different level of meat raw material replacement with hydrated animal proteins in the range of $10 \%$ to $30 \%$ with an increment of $10 \%$ were used as the model minced meat. Hydration of animal proteins was carried out with the protein: water ratio of 1:10 for beef minced meat and 1:8 for pork minced meat.

The samples of beef and semi-fat pork were used as a control: control 1 - trimmed beef of top grade with mass fraction of connective and fat tissues not more than $3 \%$; control 2 - trimmed beef of the second grade with mass fraction of connective and fat tissues not more than $20 \%$, control 3 - trimmed semi-fat pork with mass fraction of fat and connective tissues not more than $45 \%$. The hydrated animal protein was added to the experimental samples in amounts of $10 \%, 20 \%$ and $30 \%$ of the meat raw material mass. Table salt was added to all samples in an amount of $2.2 \%$. Based on the functional-technological characteristics of meat raw material, water was further added to all samples: to the control samples in an amount of $25 \%$ and to the experimental samples on the basis of decrease in the mass fraction of meat raw material. Trimmed meat raw material with the specified content of fat and connective tissues was minced in a grinder with 2-6-mm-diameter grinder plates. Then, minced meat raw material was mixed in a mixer with table salt, water with a temperature of not higher than $4{ }^{\circ} \mathrm{C}$ and preliminary hydrated animal protein until the homogeneous distribution of all ingredients. Each of the obtained samples was divided into two parts: one part was sent for performing the planned experiments; the second was formed and cooked in a water bath at a heating medium temperature of $75^{\circ} \mathrm{C}$ and relative humidity of $100 \%$ until reaching a sample core temperature of $70-72{ }^{\circ} \mathrm{C}$. After thermal treatment, the samples were cooled until reaching a sample core temperature of $6^{\circ} \mathrm{C}$. The samples of minced meat subjected to thermal treatment were analyzed after cooling.

The prepared samples (control and experimental) were sent for determination of the following indicators:

- determination of the physico-chemical characteristics:

- $\mathrm{pH}$ value was determined with portable $\mathrm{pH}$ meter " $\mathrm{Za}$ mer" (model 2696) by direct measurement in different points of a sample;

- mass fraction of total moisture was determined by the 
и подвергали термической обработке в водяной бане при температуре греющей среды $75^{\circ} \mathrm{C}$ и относительной влажности $100 \%$ до достижения температуры в центре образца 70-72 ${ }^{\circ} \mathrm{C}$. После тепловой обработки образцы охлаждали до достижения температуры в центре образца $6^{\circ} \mathrm{C}$. Образцы фаршей, подвергнутые тепловой обработке исследовали после охлаждения.

Изготовленные образцы (контрольные и опытные) направлены на испытание по следующим показателям: - определение физико-химических характеристик:

- величина $\mathrm{pH}$ - определяли портативным $\mathrm{pH}$-метром «Замер» (модель 2696) прямым измерением в различных точках образца;

- массовая доля общей влаги - методом, основанным на высушивании образца до постоянной массы при $105^{\circ} \mathrm{C}$;

- - массовая доля общего белка - методом, основанным на определении белка методом по Къельдалю.;

- - массовая доля жира - методом, основанным на определении жира методом по Сокслету;

- оксипролин -методом, основанным на выделении оксипролина при кислотном гидролизе пробы продукта, проведении цветной реакции с продуктами окисления ее с образованием соединения красного и измерении интенсивности окраски;

- коллаген определяли расчетным путем умножением массовой доли оксипролина на коэффициент пересчета 8,07;

- определение динамической вязкости осуществляли методом, основанным на определении силы, действующей на единичную площадь поверхности, которая перемещается с единичной скоростью относительно другой поверхности;

- определение влагосвязывающей способности (BCC) и влагоудерживающей способности (ВУС) методом прессования навески под нагрузкой в 1 кг и последующем расчете по разнице масс до и после пресования и площади вляжного пятна, определенного планиметром, по Р.Грау и Р.Хамму в модификации В.Воловинской и Б.Кельман и выражали в \% к общей массе влаги в продукте ;

- определение цветовых характеристик осуществляли на компьютеризированном спектроколориметре (Спектротон, Россия). Принцип работы прибора основан на одновременном измерении коэффициентов отражения образцов на 24 фиксированных длинах волн, расположенных через 13 нм в видимой области спектра от 380 до 720 нм, с последующей математической обработкой результатов измерения микропроцессорным контроллером, встроенным в измерительный блок. Прибор измеряет: координаты цвета МКО (1931 г.) - X, Y, Z; координаты цветности - X, у; координаты цвета CIELab (1976 г.) - L (светлота), a* (краснота), $\mathrm{b}^{*}$ (желтизна) и другие показатели.

\section{Результаты и обсуждения}

Для разработки методологии прогнозирования качества вареных колбасных изделий необходимо провести анализ методов, используемых для решения аналогичных задач различными авторами. method of specimen drying to the constant mass at $105^{\circ} \mathrm{C}$; - mass fraction of total protein was determined by the Kjeldahl method;

- mass fraction of fat was determined by the Soxhlet method;

- oxyproline was determined by the method based on oxyproline release at oxidative hydrolysis of a product specimen, color reaction of the products of its oxidation with development of a red compound and measurement of color intensity.

- collagen was determined by the calculative method multiplying the mass fraction of oxyproline by a conversion factor of 8.07;

- dynamic viscosity was determined by the method based on measurement of a force acting on a unit area of a plane, which moves at a unit velocity with respect to another plane;

- moisture binding capacity (MBC) and moisture holding capacity (MBC) were determined by pressing of a specimen under a press of $1 \mathrm{~kg}$ and subsequent calculation of the difference in masses before and after pressing and the area of wet spot detected by a planimeter according to the Grau - Hamm filter-paper press method in modification of Volovinskaya-Kelman and were expressed in percents of the total moisture of a product;

- determination of the color characteristics was carried out on the spectrocolorimeter (Spectroton, Russia). The principle of operation of the apparatus is based on the simultaneous detection of the reflection coefficients of samples on 24 fixed wavelengths located at a distance of $13 \mathrm{~nm}$ in the visible spectrum (380-720 nm) with the subsequent mathematical processing of the measurement results with a microprocessor controller, installed into the measurement block. The apparatus measures the CIE XYZ color space (1931); color coordinates - x, y; CIE $1976\left(L^{*}, a^{*}, b^{*}\right)$ color space (L - lightness; $\mathrm{a}^{\star}$-redness, $\mathrm{b}^{\star}$-yellowness) and other indicators.

\section{Results and discussions}

To develop a methodology for cooked sausage quality prediction, it is necessary to carry out an analysis of the methods used for solving the similar tasks by different authors.

In designing food products with a complex raw material composition, a possibility of modeling the characteristics of a finished product, predicting its quality and functional-technological properties is of high importance.

At present, the methods of linear experimental statistical programming and the object-oriented approach are mainly used for designing recipes of multicomponent food products.

Design of the combined food products is based on the principle of food combinatorics, which is a process of developing recipes of new types of products by substantiated quantitative selection of the main raw material, ingredients, food and biologically active additives, which combination ensures the formation of the required organoleptic and physico-chemical properties of products as well as the specified level of food, biological and energy values [6,7].

The process of optimization of the recipe composition is based on the use of the calculative criteria and concepts proposed by I.A. Rogov, N.N. Lipatov and A.B. Lisitsyn, as 
При проектировании пищевых продуктов сложного сырьевого состава большое значение имеет возможность моделирования характеристик готового продукта, прогнозирования его качества и функционально-технологических свойств.

В настоящее время для проектирования рецептур многокомпонентных пищевых продуктов в основном используются методы линейного, экспериментальностатистического программирования и объектно-ориентированного подхода.

Проектирование комбинированных продуктов питания основано на принципе пищевой комбинаторики, т.е. процесс создания рецептур новых видов продуктов путем обоснованного количественного подбора основного сырья, ингредиентов, пищевых и биологически активных добавок, совокупность которых обеспечивает формирование требуемых органолептических, физико-химических свойств продукта, а также заданный уровень пищевой, биологической и энергетической ценности $[6,7]$.

Процесс оптимизации состава рецептур основан на использовании расчетных критериев и понятий, предложенных И.А. Роговым, Н.Н. Липатовым и А.Б. Лисицыным, а также в работах Ю.А. Ивашкина по структурно-параметрическому моделированию и структурной оптимизации технологических систем.

В последние десятилетия в этом направлении также проводились научные исследования.

При разработке оптимальных рецептур молочных продуктов [8] повышенной биологической ценности применяется методология экспериментально-статистического моделирования. Методология основывается на выделении ключевого нутриента моделирования и оптимизации его качества.

Сатиной О.В. и Юдиной С.Б. [9] предложена методика проектирования рецептур мясных продуктов, включающих в себя три этапа моделирования: моделирование аминокислотного состава проектируемого продукта и выбор значений, в наибольшей степени удовлетворяющих критерию; оценка жирнокислотного состава проектируемого продукта; расчет энергетической ценности проектируемого продукта. В качестве критерия использовалась квалиметрическая мультипликативная модель, позволяющая свести в одну форму относительные комплексные и простые единичные показатели качества различного характера, обеспечивающие независимость свойств каждого из показателей. Процесс моделирования геронтологических продуктов осуществлялся авторами в общем виде циклическим алгоритмом, предложенным Липатовым Н.Н.

В работе Муратовой Е.И. и др. [10] используется объектно-ориентированный подход. Отличительной особенностью данного метода является представление рецептуры в виде иерархической структуры. Каждая из вершин иерархической структуры представляет собой объект (готовый продукт, полуфабрикат, сырье). Каждый уровень иерархии соответствует определенной стадии изготовления пищевого продукта и может иметь свое, индивидуальное число вершин, расположенных ниже по иерархии. Алгоритм расчета многокомпонентного продукта начинается с well as in the works of Yu.A. Ivashkin on the structuralparametric modeling and structural optimization of technological systems.

The work in this direction has been also carried out over the last decades.

In design of the optimal recipes of dairy products [8] with increased biological value, the methodology of the experimental statistical modeling is used. The methodology is based on the determination of the key nutrient of modeling and optimization of its quality.

Satina O.V. and Yudina S.B. [9] proposed a methodology for designing meat product recipes, which includes three stages of modeling: modeling of the amino acid composition of a product under design and selection of the values that meet a criterion to the fullest extent possible; assessment of the fatty acid composition of a product under design; calculation of the energy value of a product under design. As a criterion, a qualimetric multiplicative model was used, which allows convolving the relative complex and simple single quality indicators with different characters into one form ensuring independence of the properties of each indicator. The authors performed a process of modeling of the gerontological products in a general form with the cyclic algorithm proposed by Lipatov N.N.

Muratova E.I. et al. [10] used the object-oriented approach in their work. The distinctive characteristic of this method is presentation of a recipe in a form of a hierarchical structure. Each peak of a hierarchical structure presents an object (a finished product, semi-prepared product, raw material). Each level of a hierarchy corresponds to a particular stage of food product preparation and can have its individual number of peaks located down through the hierarchy. An algorithm of calculating a multicomponent product begins with calculation of the last level with the longest branch of a hierarchical structure of calculation. The main advantage of this approach is a solution to a task of a multicriteria optimization.

The work [11] on the basis of the mathematical models and recursive cycle shows the algorithm of modeling polycomponent mixtures that ensure obtaining a necessary set of options and their composition according to a criterium of macro- and micronutrient composition.

Bessonova L.I. [12] developed a quality function according to consumer preferences, as well as QFD for food products based on detection of a autocorrelation function that allows building a predictive model for management of prospect indicators of technological processes, ready food products and services.

Therefore, computer design of a recipe composition of food products is methodically well mastered [8-12], supported by the mathematical apparatus and information base, which, as a result, allows obtaining a set of preferable compositions that meet the formalized requirements.

However, "an optimal recipe" obtained by this means does not guarantee a transformation during technological processing into a stable meat system with required organoleptic indicators, structural-mechanical properties, yield and so on. This is conditioned by the fact that individual components of recipes have quite specific individual and often mutually exclusive functional-technological properties.

Thus, to predict quality of future products, it is nec- 
расчета последнего уровня с наиболее длинной ветви иерархической структуры расчета. Основным достоинством данного подхода является решение задачи многокритериальной оптимизации.

В работе [11] на базе математических моделей и рекурсивного цикла показан алгоритм моделирования поликомпонентных смесей, обеспечивающих получение необходимого набора вариантов и их состава по критерию макро- и микронутриентного состава.

Бессоновой Л.И. [12] разработана функция качества в соответствии с потребительскими предпочтениями, а также СФК для пищевых продуктов, основанную на определении автокорреляционной функции, позволяющий построить прогнозную модель управления перспективными показателями технологических процессов, готовых пищевых продуктов и услуг.

Таким образом, компьютерное проектирование рецептурного состава пищевых продуктов методически хорошо освоен [8-12], подкреплен математическим аппаратом и информационной базой, что позволяет в результате проектирования получать набор предпочтительных композиций, удовлетворяющих формализованным требованиям.

Однако, полученная таким образом «оптимальная рецептура» не гарантирует превращения в процессе технологической обработки в устойчивую мясную систему с требуемыми органолептическими показателями, структурно-механическими свойствами, выходом и т.д. Это обусловлено тем, что отдельные компоненты рецептур обладают вполне определенными индивидуальными и часто - взаимоисключающими функционально-технологическими свойствами.

Поэтому для прогнозирования качества будущей продукции необходимо располагать информацией не только о химическом составе и биологической ценности отдельных компонентов рецептур, но и данными о фактических значениях функционально-технологических свойств основного сырья, вспомогательных ингредиентов, кинетике протекания биохимических и коллоидных процессов в многокомпонентных пищевых системах, аналитическими и эмпирическими зависимостями, характеризующими основные закономерности поведения гетерогенных дисперсных систем при варьировании физико-химических факторов [7].

В этом направлении определенный интерес представляют работы [13-14], в которых описывается решение задачи оптимизации рецептуры с учетом реологических показателей, таких как ВУС, ЖУС, ВСС, pН. В качестве целевой функции выбран критерий минимальной себестоимости многокомпонентного продукта.

В работах ряда авторов [15-17] рассматривается задача имитационного моделирования взаимодействия популяций микроорганизмов, как средство диагностирования и прогнозирования развития микробиоценозов. Решение этой задачи позволяет реализовать оперативное управление процессами производства и оптимизацию технологических параметров в режиме реального времени, а также открывает возможности к созданию систем автоматизированного проектирования штаммов микроорганизмов с целью получения продуктов с заданными свойствами. essary to have information not only about the chemical composition and biological value of individual recipe components, but also the data on the actual values of the functional-technological properties of the main raw material, auxiliary ingredients, kinetics of biochemical and colloid processes in the multicomponent food systems, analytical and empirical dependences that characterize the regularities of the behavior of the heterogeneous disperse systems upon variation of physico-chemical factors [7].

In this regard, the works [13-14], which describe a solution to the task of a recipe optimization with consideration for the rheological indicators such as $\mathrm{MHC}, \mathrm{FHC}$, $\mathrm{MBC}$ and $\mathrm{pH}$ are of particular interest. The criterion of the minimal cost of a multicomponent product was chosen as a target function.

The works of several authors [15-17] examine the task of the simulation modeling of the interaction of microorganism populations as a means of diagnostics and prediction of microbiocenosis development. Solving this task enables realization of the operative management of production processes and optimization of technological parameters in the real time regime, and also opens a possibility to develop systems of the automated design of microorganism strains with the aim to obtain products with specified properties.

The work [18] examines a computer-based safety and quality assurance system for raw air-dried sausages. The developed system is intended for creation of a bank of simulation models that makes it possible to analyze and predict the results of the processes of air-dried sausage production and detect the optimal management effects on a studied object.

An analysis of the literature sources shows that designing multicomponent food products is largely carried out by the criteria of food, biological and energy value without consideration for the functional-technological indicators and structural-mechanical properties. The issues of prediction are mainly examined on the fermented meat products (uncooked smoked and air-dried sausages).

Based on the foregoing, it is interesting to obtain simulation models for predicting results of the processes of cooked sausage production, create a bank of models and develop a software. To this end, it is necessary to obtain a statistical material with its further processing for investigation of the real technologies used in the conditions of the informational uncertainty caused by various factors of the informational and physical character (uncertainty of the characteristics of food raw material, used means of processing and control, target criteria of management and so on).

The most important requirement according to the International standards of the ISO 9000 family is an active use of the statistical methods for decision making at all stages of a product life cycle.

The prominent specialist in the field of quality management K. Ishikawa $[19,20]$ stated that the statistical methods were precisely the means that were necessary to study for implementation of quality control.

An analysis of the obtained data on this stage of the investigation was carried out by the methods of the correlation-regression analysis [21] for obtaining the stochastic dependences forming a bank of the mathematical models 
В работе [18] рассматривается компьютерная система обеспечение качества и безопасности сыровяленых колбас Разработанная система предназначена для создания банка имитационных моделей, позволяющих анализировать и прогнозировать результаты процессов производства сыровяленых колбасных изделий и определять оптимальные управленческие воздействия на исследуемый объект.

Анализ литературных источников показал, что в основном проектирование многокомпонентных продуктов питания осуществляется по критериям пищевой, биологической и энергетической ценности без учета функционально-технологических показателей и структурно-механических свойств. Вопросы прогнозирования в основном рассмотрены на ферментированных мясных изделиях (сырокопченых и сыровяленых колбасах).

На основании вышеизложенного представляет интерес получение имитационных моделей прогнозирования результатов процессов производства вареных колбас, создание банка моделей и разработки программного обеспечения. Для этого необходимо получить статистический материал с последующей его обработкой для исследования реальных технологий, действующих в условиях информационной неопределенности, обусловленной различными факторами информационного и физического характера (неопределенность характеристик пищевого сырья, применяемых средств воздействия и контроля, целевых критериев управления и т.д.).

Важнейшим требованием, согласно Международным стандартам серии ИСО 9000 является активное использование статистических методов для принятия решений на всех этапах жизненного цикла продукции.

Крупнейший специалист в области управления качеством К. Исикава $[19,20]$ говорил: «Методы статистики - именно то средство, которое необходимо изучить, чтобы внедрить управление качеством».

Анализ полученных данных на данном этапе исследований осуществлялся методами корелляционо-регрессионного анализа [21] для получения стохастических зависимостей, формирующих банк математических моделей, позволяющий реализовать любой вариант замены мясного сырья животными белками (свиными и говяжьими) в рамках имитационного эксперимента с учетом реальной технологической ситуации в производстве вареных колбас.

Как видно из гистограмм с группировкой (рис. 1,2$)$, применяемой для сравнения значений по нескольким категориям, видно отличие опытных образцов от контроля. Анализ полученных результатов показывает, что замена мяса гидратированным говяжьим животным белком в количестве 10 и $20 \%$ в образцах, выработанных на основе говядины жилованной высшего сорта приводит к снижению общего белка по сравнению с контрольными образцами на 3-8\%. Замена мяса говяжьим животным белком в количестве $30 \%$ снижает содержание белка на 13\%. Такая же тенденция наблюдается и у that allow realization of any options for replacement of meat raw material with animal proteins (pork and beef) in the framework of a simulation experiment using a real technological situation in cooked sausage production.

As can be seen from the histograms with grouping (Fig. 1, 2) used for comparison of the values by several categories, a difference of the experimental samples from the control is obvious. An analysis of the obtained results demonstrated that replacement of meat with the hydrated beef protein in amounts of $10 \%$ and $20 \%$ in the samples produced on the basis of trimmed beef of top grade led to a decrease in total protein by $3-8 \%$ compared to the control samples. Replacement of meat with beef protein in an amount of $30 \%$ reduced the content of protein by $13 \%$. The same trend was also observed in the samples produced with trimmed beef of the 2 nd grade. Replacement of 10 and $20 \%$ of meat with beef protein decreased total protein by $3-10 \%$, respectively; and replacement of $30 \%$ of meat raw material reduced total protein by $19 \%$.

In the samples produced on the basis of semi-fat trimmed pork, replacement of meat with animal protein in amounts of 10, 20 and $30 \%$ led to a decrease in protein by 7,8 and $12 \%$, respectively.

With an increase in the dose of the hydrated beef protein, the moisture content increased and the content of total protein and fat decreased in the experimental samples compared to the control.

Addition of the hydrated pork protein in amounts of 10 , 20 and $30 \%$ led to an increase in collagen in all samples and a decrease in total protein compared to the control sample.

In the samples produced from trimmed beef of top grade, a decrease in total protein was 6, 9 and $10 \%$, and in the samples produced from trimmed beef of the 2 nd grade, a decrease in total protein was 11, 15 and 19\%.

Reduction of protein in the samples produced from semi-fat pork was 7, 13 and $14 \%$, respectively.

In the experimental samples produced with the hydrated animal proteins, a decrease in protein and fat was observed as their dose increased; it was especially noticeable in the samples produced from fattier raw material, such as trimmed beef of the 2 nd grade and semi-fat trimmed pork.

Determination of the mass fraction of collagen in the analyzed samples showed that upon increasing a dose of animal protein incorporation, an increase in the collagen content was recorded, which was predictable since it is the main protein of animal proteins. This, undoubtedly, was conditioned by a composition of raw material, from which animal proteins were obtained.

The obtained experimental data showed that the collagen content in the samples produced from semi-fat trimmed pork was noticeably lower than in the beef samples, which can be explained by the difference in the amino acid composition of pork and beef.

As a result of processing of the experimental data by the methods of the correlation and regression analysis, the linear relationship of the type $y=b+a x$ was established between the percentage of meat raw material replacement with animal protein (beef or pork) and the physico-chemical indicators of minced meat (Table 1).

The quality of finished meat products directly depends on minced meat quality. An analysis of the experimental 

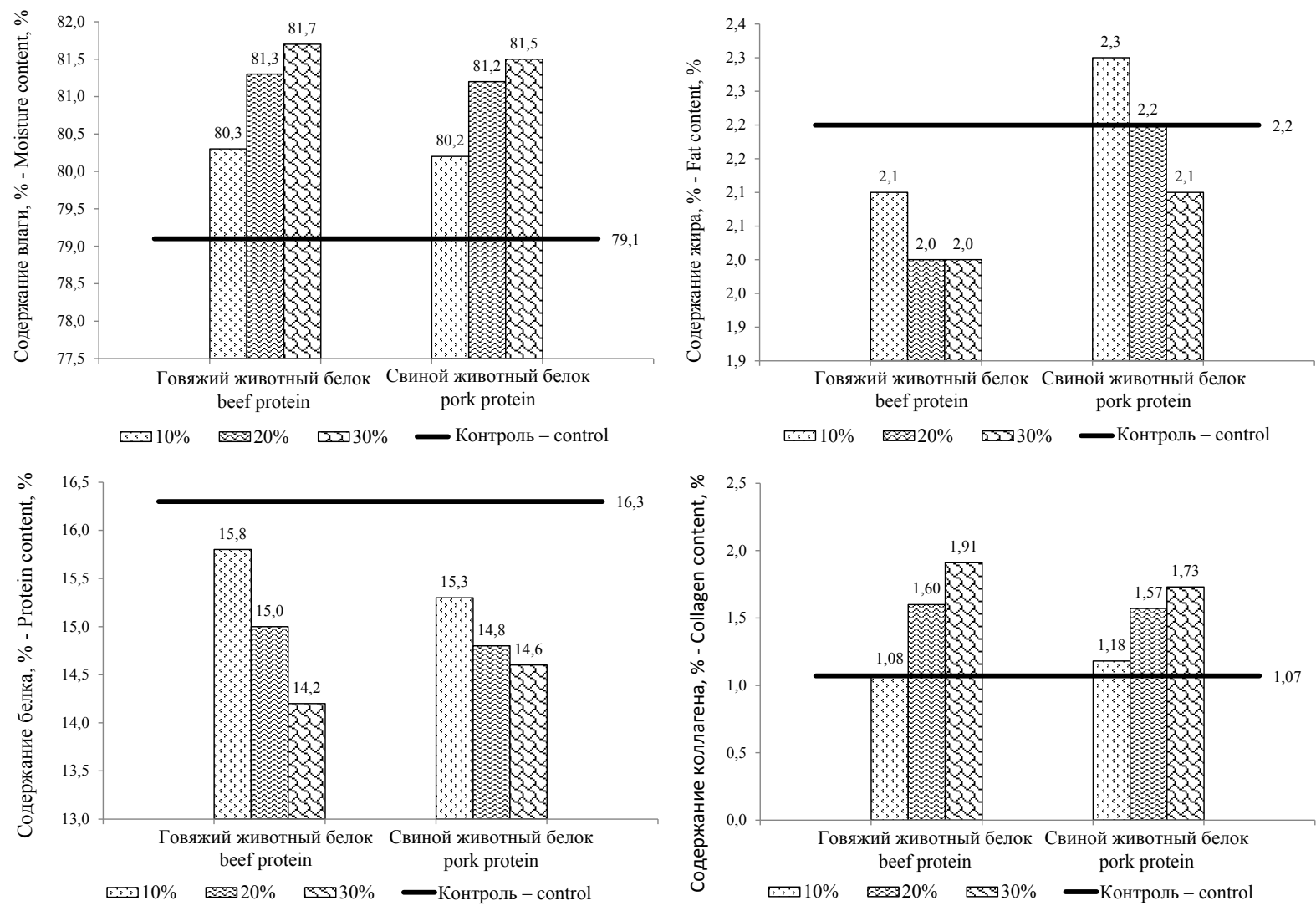

Fig. 1 - Dynamics of the changes in the chemical composition of the experimental model system by the example of trimmed beef of top grade (control sample 1)

Рис. 1 - Динамика изменения химического состава опытных модельных систем на примере говядины жилованой высшего сорта (контрольный образец 1)
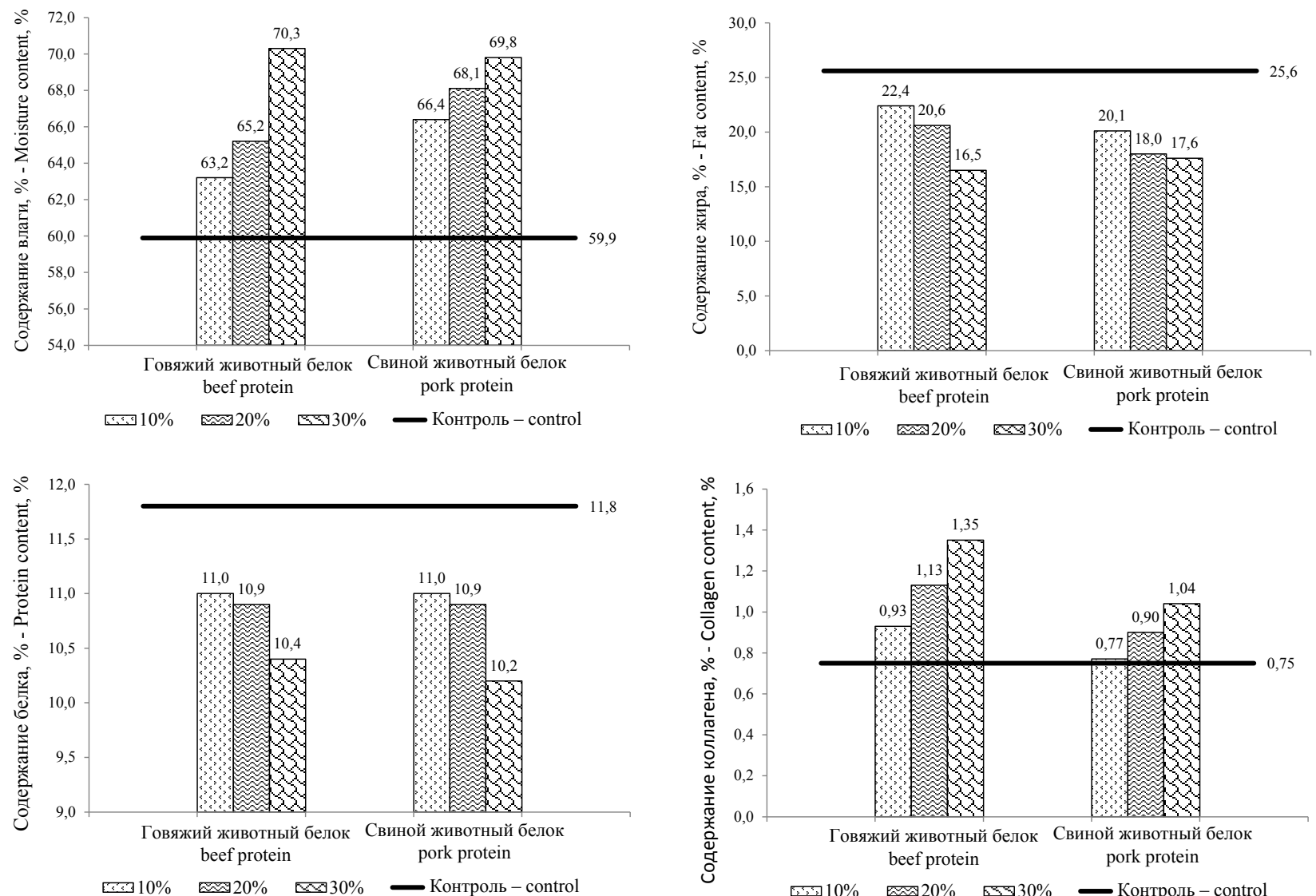

Fig. 2 - Dynamics of the changes in the chemical composition of the experimental model system by the example of trimmed semi-fat pork (control sample 3)

Рис. 2 - Динамика изменения химического состава опытных модельных систем на примере свинины жилованой полужирной (контрольный образец 3) 
образцов выработанных с говядиной жилованной 2 сорта. Замена 10 и 20\% мяса говяжьим животным белком снижает общий белок соответственно на $3-10 \%$, а замена $30 \%$ мясного сырья снижает общий белок на $19 \%$.

В образцах, выработанных на основе полужирной жилованной свинины, замена мяса животным белком в количестве 10, 20, 30\% приводит к снижению белка, соответственно, на 7, 8, 12\%.

С увеличением дозы гидратированного животного говяжьего белка увеличивается содержание влаги и снижение общего белка и жира в опытных образцах по сравнению с контрольными образцами.

Добавление гидратированного животного свиного белка в количестве 10, 20, 30\% ведет к увеличению коллагена во всех образцах и снижению общего белка по сравнению с контрольным образцом.

У образцов, выработанных из говядины жилованной высшего сорта снижение общего белка составляет 6, 9, 10\%, а у образцов, выработанных из говядины жилованной 2 сорта снижение общего белка составляет соответственно 11, 15, $19 \%$.

Снижение белка в образцах, выработанных из свинины полужирной, составляет соответственно 7, 13 и 14\%.

В опытных образцах, выработанных с гидратированными животными белками, по мере увеличения их дозы наблюдается снижение не только белка, но и жира, особенно это заметно на образцах, выработанных из более жирного сырья, такого как говядина жилованная 2 сорта и свинина жилованная полужирная.

Определение массовой доли коллагена в исследуемых образцах показало, что при увеличении внесения животного белка отмечается увеличение содержания коллагена в образцах, что является прогнозируемым, поскольку именно он является основным белком животных белков. Что, конечно, обусловлено составом сырья, из которого производятся животные белки.

Полученные экспериментальные результаты показали, что содержание коллагена в образцах, выработанных из свинины жилованной полужирной заметно ниже, чем у образцов, выработанных из говядины, что объясняется различием в аминокислотном составе свинины и говядины. data on the chemical composition and their mathematical processing made it possible to reveal the linear dependence (Table 1), which reflected the closeness and depth of the relationship with the percentage of meat raw material replacement with animal proteins as the paired correlation coefficient, which was close by a module to 1 , indicated a strong linear relationship between the resultant and factor variables.

Moisture binding capacity (MBC) of meat raw material is of high practical importance; it significantly influences such quality characteristics of finished meat products as consistency, storage stability and yield of finished products.

Moisture binding capacity is one of the most important indicators of raw sausage meat for cooked sausage products. As a result of the physico-chemical and colloidchemical changes, which occur during the process of thermal treatment, a part of water and fat bound in raw sausage meat separates in a form of mass loss or broth-fat purge. An amount of moisture and fat held in minced meat characterizes the moisture holding (MHC) and fat holding (FHC) capacities; that is, the higher cooking losses, the lower the moisture holding capacity of minced meat.

Moisture binding capacity (MBC) depends not only on the total protein content, but also on its quality; with that, it is necessary to take into account an amount of fat. With an increase in fat mass, $\mathrm{MBC}$ reduces. In this connection, moisture binding capacity of the samples produced from trimmed beef of top grade is higher than in the samples produced from pork.

When animal proteins in the hydrated form were incorporated into minced beef in amounts of 10 and 20\%, MBC of these samples was at the same level as in the control (75-78\%); however, when the mass fraction of the incorporated proteins increased up to $30 \%, \mathrm{MBC}$ reduced by $2 \%$ in contrast to the control sample.

When animal proteins in the hydrated form were incorporated into minced pork, MBC in the experimental samples was $57-58 \%$ when comparing them between each other and the control.

Moisture holding capacity (MHC) of minced meat has lower values compared to moisture binding capacity (MBC) as proteins denature during thermal treatment, which leads to loss of part of moisture. The MHC values of

Table 1 Values of the paired correlation coefficients and regression equation

Таблица 3. Жирнокислотный состав масел, входящих в состав исследуемых продуктов

\begin{tabular}{|c|c|c|}
\hline \multirow{2}{*}{$\begin{array}{c}\text { Physico-chemical indicators } \\
\text { Физико-химические } \\
\text { показатели }\end{array}$} & \multicolumn{2}{|c|}{ Trimmed beef of top grade | Говядина жилованная высшего сорта } \\
\hline & Beef protein | Говяжий белок & Pork protein | Свиной белок \\
\hline Moisture | Влага & $r=0.971 ; y=79.7+0.07 x$ & $r=0.955 ; y=79.67+0.065 x$ \\
\hline Fat $\mid$ Жир & $r=-0.866 ; y=2.13+0.005 x$ & $r=-1 ; y=2.4+0.01 x$ \\
\hline Protein | Белок & $r=-1 ; y=16.6+0.08 x$ & $r=-0.971 ; y=15.6+0.035 x$ \\
\hline \multirow[t]{2}{*}{ Collagen | Коллаген } & $r=0.989 ; y=0.7+0.0415 x$ & $r=0.972 ; y=0.94+0.0275 x$ \\
\hline & \multicolumn{2}{|c|}{ Trimmed semi-fat pork | Свинина жилованная полужирная } \\
\hline Moisture | Влага & $r=0.97 ; y=59.13+0.355 x$ & $\mathrm{r}=1 ; \mathrm{y}=64.7+0.17 \mathrm{x}$ \\
\hline Fat | Жир & $r=-0.976 ; y=25.73+0.295 x$ & $r=-0.931 ; y=21.07+0.125 x$ \\
\hline Protein | Белок & $r=-0.933 ; y=11.37+0.03 x$ & $r=-0.918 ; y=11.5+0.04 x$ \\
\hline Collagen | Коллаген & $\mathrm{r}=0.999 ; \mathrm{y}=0.72+0.021 \mathrm{x}$ & $r=0.999 ; y=0.63+0.0135 x$ \\
\hline
\end{tabular}


В результате обработки экспериментальных данных методами корреляционно-регрессионного анализа была установлена прямолинейная взаимосвязь вида $\mathbf{y}=\mathbf{b}+\mathbf{a x}$ между процентом замены мясного сырья животным белком (говяжьим или свиным) и физикохимическими показателями мясного фарша (табл. 1).

Качество готовых продуктов находится в прямой зависимости от качества мясного фарша. Анализ экспериментальных данных по химическому составу и их математическая обработка позволили выявить прямолинейную зависимость (табл. 1), которая отражает тесноту и глубину связи между процентом замены мясного сырья животными белками, так как коэффициент парной корреляции близкий по модулю к 1 свидетельствует о сильной линейной связи между результирующими и факторными переменными.

Большое практическое значение имеет влагосвязывающая способность (ВСС) мясного сырья, она оказывает существенное влияние на такие качественные характеристики готовых мясных изделий, как консистенция, устойчивость при хранении, а также выход готовой продукции.

Влагосвязывающая способность является одним из важнейших показателей сырого фарша вареных колбасных изделий. В результате происходящих в процессе термической обработки физико-химических, коллоидно-химических изменений часть воды и жира, связанные в сыром фарше отделяются в виде потерь массы или в виде бульонно-жировых отеков. Количество удержанных в составе фарша влаги и жира характеризует влагоудерживающая (ВУС) и жироудерживающая (ЖУС) способности, т.е., чем больше термические потери, тем меньше влагоудерживающая способность фарша.

Влагосвязывающая способность (ВСС) образцов зависит не только от общего содержания белка, но и от его качества, при этом также необходимо учитывать количество жира. С увеличением массы жира ВСС снижается, в связи с этим у образцов, выработанных из говядины жилованной высшего сорта она выше, чем у образцов, выработанных из свинины.

При внесении в говяжий фарш животных белков в гидратированном виде в количестве 10 и 20\% влагосвязывающая способность в этих образцах в сравнении с контрольным образцом была на одном уровне и составляла 75-78\%, однако при увеличении массовой доли вносимых белков до 30\% снижалась на 2\% в отличие от контрольного образца.

При внесении в свиной фарш животных белков в гидратированном виде влагосвязывающая способность в опытных образцах в сравнении между собой и с контрольным образцом составляла 57-58\%.

Влагоудерживающая способность (ВУС) фаршей имеет более низкие значения по сравнению с влагосвязывающей способностью (ВСС), так как белки при тепловой обработке денатурируют, что приводит к потере части влаги. Значения ВУС всех исследуемых образцов были на 7-9\% ниже значений их влагосвязывающей способности. Потери при термической обработки исследуемых образцов all tested samples were 7-9\% lower than the MBC values. Cooking losses in the tested control and experimental samples with the hydrated animal protein content in amounts of 10 and $20 \%$ were at the same level and were equal to $10 \%$; upon increasing the hydrated protein level up to $30 \%$, the losses increased by $2 \%$.

To establish the maximum allowable level of meat raw material replacement with animal proteins, the principle [22] was taken into account, which ensures high functional properties of minced meat (moisture and fat holding capacities). The principle is based on the fact that the highest binding of water in a mixture can be achieved at the specific fat:protein ratio, and the highest holding of fat at the specific moisture:protein ratio. Distortion of these ratios leads to the irrational use of protein.

The emulsifying capacity of protein is restricted; thus, the most optimal fat:protein ratio in homogenized minced meat is a range from $0.6: 1.0$ to $0.8: 1.0$. In the national practice, the optimal protein:fat:water ratio is considered to be at a level of $1: 0.8:(3 \div 5)$.

The control of a muscle protein content in an emulsion is the main prerequisite for producing stable meat systems. A high content of total protein (both muscle and connective tissue) does not indicate a high level of the potential emulsifying capacity, as collagen in the native form does not take part in the process of fat absorption, emulsification and stabilization of emulsions. These functions are accomplished by muscle proteins.

As a result of the mathematical processing, it was established that the maximum allowable level of meat raw material replacement was $18 \%$ for beef and $22 \%$ for pork.

One of the main organoleptic characteristics is a product color. The color characteristics were determined for the instrumental evaluation of changes in minced meat color upon incorporation of animal proteins. Table 2 presents the indicators of color characteristics.

As can be seen from table 2, replacement of meat with $10 \%$ of the hydrated animal proteins (both beef and pork) in samples No. 1 led to an increase in lightness (L: 45.04 and 44.21) and an insignificant decrease in redness (a: 13.97 and 13.62) compared to the control and the value of yellowness remained at the level of the control sample.

Samples No 2 (both with beef and pork) showed a significant decrease in redness and insignificant decrease in yellowness; while the value of lightness increased.

A sharp decrease in redness (a: 9.87 and 9.31) was observed in samples No.3 produced with $30 \%$ of hydrated animal proteins; while lightness and yellowness significantly increased compared to the control and experimental samples.

The obtained results of the instrumental investigation of minced meat color showed that incorporation of the hydrated animal proteins in an amount of up to $10 \%$ decreased redness by $3 \%$, which was undetectable in organoleptic assessment.

According to the experimental data, the adequate models were built for the changes in mass fraction of moisture, fat, protein and collagen (Table 1) in replacement of meat raw material with animal proteins (beef and pork). The diagrams for several models are presented in Fig. 3. 
у контрольных и опытных образцов с содержанием гидратированного животного белка в количествах 10 и 20\% были на одном уровне и составили 10\%, при увеличении гидратированного белка до $30 \%$ потери увеличивались на $2 \%$.

Для установления предельно допустимого уровня замены мясного сырья животными белками был учтен принцип [22], обеспечивающий высокие функциональные свойства мясного фарша (влаго- и жироудерживающая способность). Принцип основывается на том, что наибольшего связывания воды в смеси можно достичь при определенном соотношении жир : белок, а наибольшего удержания жира - при определенном соотношении влага : белок. Нарушение этих соотношений приводит к нерациональному использованию белка.

Эмульгирующая способность белка ограничена, поэтому наиболее рациональным соотношением жир:белок в гомогенизированных фаршах является диапазон от 0,6:1,0 до 0,8:1,0. В отечественной практике принято считать оптимумом соотношение белок:жир:вода равное 1:0,8:(35).

Контроль за содержанием мышечного белка в эмульсии - главное условие получения стабильных мясных систем. Высокое содержание общего белка (и мышечной и соединительной ткани) еще не свидетельствует о высоком уровне потенциальной эмульгирующей способности, так как коллаген в нативном виде не участвует в процессе жиропоглощения, эмульгирования и стабилизации эмульсий. Эти функции выполняют только мышечные белки.

В результате математического расчета было получено, что предельно допустимый уровень замены мясного сырья составляет 18\% для говядины и 22\% для свинины.

Одной из основных органолептических характеристик является цвет продукта. Для инструментальной оценки изменения цвета фарша при внесении животных белков были определены цветовые характеристики. В табл. 2 представлены показатели цветовых характеристик.
A comparative analysis of the obtained models and constructed diagrams allows suggesting almost full identity of the models and, as a consequence, using some averaged models in the prediction tasks.

Product quality assurance consists of the minimal deviation from the specified (set) structure of the physicochemical indicators determining food value

$$
P(z)=\sum_{i=1}^{n}\left(z_{i}^{0}-\sum_{j=1}^{m} b_{i j} x_{j}\right)^{2} \rightarrow \min
$$

where $x_{j}=$ mass fraction of the $\mathrm{j}^{\text {th }}$ recipe component;

$b_{i j}=$ proportion of the $\mathrm{i}^{\text {th }}$ element of the chemical composition in the $\mathrm{j}^{\text {th }}$ recipe component of a product under design, \%;

$z_{i}^{0}=$ content of the $\mathrm{i}^{\text {th }}$ element of food value, $\%$ according to GOST, TU and TI.

As a result of the mathematical processing, it was established that the maximum allowable level of meat raw material replacement was $18 \%$ for beef and $22 \%$ for pork.

The accumulated experimental and statistical material is intended for creation of a bank of simulation models enabling analysis and prediction of changes in a meat system when replacing meat raw material with animal proteins.

The present work demonstrates the first stage of investigations, where the experiments were carried out separately on beef and pork. However, in cooked sausage production, the industry uses, as a rule, different percent ratios of these kinds of meat raw material. Therefore, the next stage of the work will be directed towards development of a model, which would allow selection of an adequate ratio of the specified kinds of raw material with animal proteins (beef and pork).

Table 2 - Color characteristics in the samples of minced meat Таблица 2 - Цветовые характеристики в образцах фарша

\begin{tabular}{|c|c|c|c|}
\hline \multirow{3}{*}{$\begin{array}{l}\text { Samples | } \\
\text { Наименование образцов }\end{array}$} & \multicolumn{3}{|c|}{ Color characteristics | Цветовые характеристики } \\
\hline & L (lightness) | L-светлота & a (redness) | а-краснота & b (yellowness) | b-желтизна \\
\hline & \multicolumn{3}{|c|}{ Arbitrary units of color | Условные единицы цвета } \\
\hline $\begin{array}{l}\text { Control } 1 \text { | } \\
\text { Контроль } 1\end{array}$ & 43.21 & 14.40 & 15.49 \\
\hline $\begin{array}{l}\text { Experiment } 1 \text { with beef protein | } \\
\text { Опыт № } 1 \text { с говяжьим белком }\end{array}$ & 45.04 & 13.97 & 15.98 \\
\hline $\begin{array}{l}\text { Experiment } 2 \text { with beef protein | } \\
\text { Опыт № } 2 \text { с говяжьим белком }\end{array}$ & 44.69 & 11.64 & 14.99 \\
\hline $\begin{array}{l}\text { Experiment } 3 \text { with beef protein | } \\
\text { Опыт № } 3 \text { с говяжьим белком }\end{array}$ & 46.48 & 9.87 & 15.43 \\
\hline $\begin{array}{l}\text { Experiment } 1 \text { with pork protein | } \\
\text { Опыт № } 1 \text { со свиным белком }\end{array}$ & 44.21 & 13.62 & 14.77 \\
\hline $\begin{array}{l}\text { Experiment } 2 \text { with pork protein | } \\
\text { Опыт № } 2 \text { со свиным белком }\end{array}$ & 43.65 & 11.32 & 14.48 \\
\hline $\begin{array}{l}\text { Experiment } 3 \text { with pork protein | } \\
\text { Опыт № } 3 \text { со свиным белком }\end{array}$ & 46.04 & 9.31 & 16.60 \\
\hline
\end{tabular}


Как видно из табл. 2 , замена мяса 10\% гидратированного животного белка, как говяжьего, так и свиного в образцах №1, вызывает увеличение показателя светлости ( $\mathrm{L}-45,04$ и 44,21) и незначительное снижение показателя красноты (a - 13,97 и 13,62), по сравнению с контролем, а показатель желтизны остается на уровне контрольного образца.

Образцы № 2 (с говяжьим и свиным белком) имеют значительное снижение показателя красноты и незначительное желтизны, а показатель светлости увеличивается.

Резкое снижение показателя красноты (a - 9,87 и 9,31) наблюдается в образцах №3, выработанных с 30\% гидратированных животных белков, и значительно возрастают показатели светлоты и желтизны по сравнению с контрольным и опытными образцами.

Полученные результаты инструментального исследования цвета фарша показали, что внесение гидратированного животного белка в количестве до 10\% на 3\% снижает показатель красноты, что неуловимо при органолептической оценке.

По экспериментальным данным были построены адекватные модели по изменению массовой доли влаги, жира, белка и коллагена (табл. 1) при замене мясного сырья животными белками (говяжьими и свиными). Графики некоторых моделей представлены на рис. 3

Сравнительный анализ полученных моделей и построенных графиков позволяет говорить о почти полной идентичности моделей и, как следствие, использовать в прогнозных задачах некоторые усредненные модели.

Обеспечение качества продукции заключается в минимальном отклонении от заданной (установленной) структуры физико-химических показателей, определяющих пищевую ценность

$$
P(z)=\sum_{i=1}^{n}\left(z_{i}^{0}-\sum_{j=1}^{m} b_{i j} x_{j}\right)^{2} \rightarrow \min
$$

где $x_{j}$ - массовая доля $j$-го компонента рецептуры;

$b_{i j}$ - удельное содержание $i$-го элемента химического состава в $j$-ом рецептурном компоненте проектируемого продукта, \%;

$z_{i}^{0}$ - содержание $i$-го элемента пищевой ценности, \% согласно ГОСТ, ТУ и ТИ.

В результате математической обработки было установлено, что предельно допустимый уровень замены мясного сырья составляет 18\% для говядины и $22 \%$ для свинины.

Накапливаемый экспериментальный и статистический материал предназначен для создания банка имитационных моделей, позволяющих анализировать и прогнозировать изменение мясной системы при замене мясного сырья животными белками.

В настоящей работе показан первый этап исследований, где опыты проводились отдельно на говядине и свинине. Однако промышленности при изготовлении вареных колбасных изделий, как правило, используются различные процентные соотношения этих видов мясного сырья. Поэтому следующий этап работы будет направлен на разработку модели, которая позволила бы подобрать адекватные соотношения указанных видов сырья с животными белками (говяжьими и свиными).
Контрольный образец 1 говядина жилованная высшего сорта - Control sample 1 trimmed beef of top grade

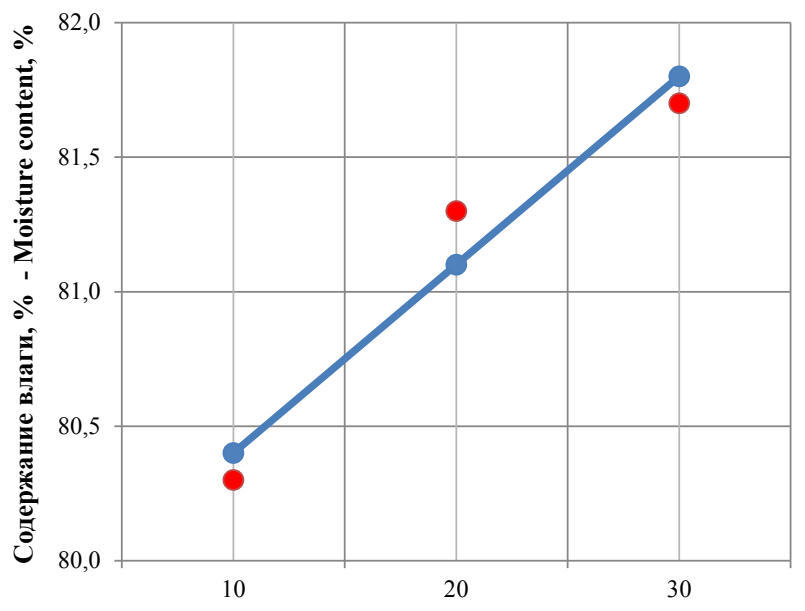

Процент замены мясного сырья говяжьим животным белком - percent of replacement of meat raw material with beef protein

--Расчетное значение - Calculated value

- Экспериментальное значение - experimental value

Контрольный образец 1 говядина жилованная высшего сорта - Control sample 1 trimmed beef of top grade

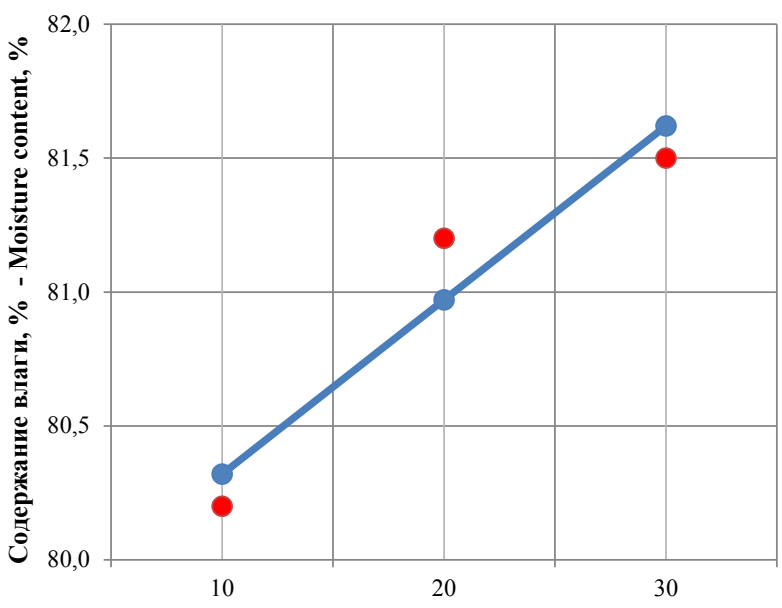

Процент замены мясного сырья свиным животным белком - percent of replacement of meat raw material with pork protein - Расчетное значение - Calculated value

- Экспериментальное значение - experimental value

Контрольный образец 1 говядина жилованная высшего copтa-Control sample 1 trimmed beef of top grade

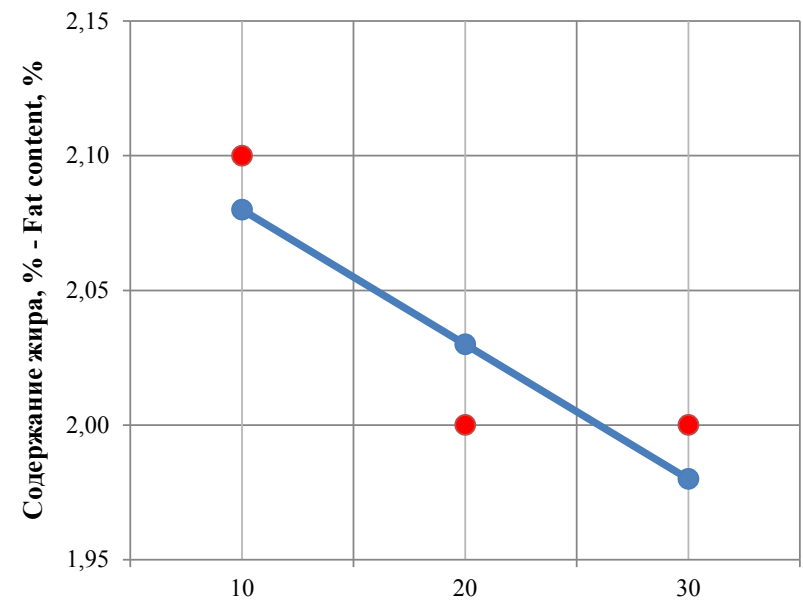

Процент замены мясного сырья говяжьим животным белком - percent of replacement of meat raw material with beef protein - Расчетное значение - Calculated value

- Экспериментальное значение - experimental value 
Контрольный образец 1 говядина жилованная высшего copта - Control sample 1 trimmed beef of top grade

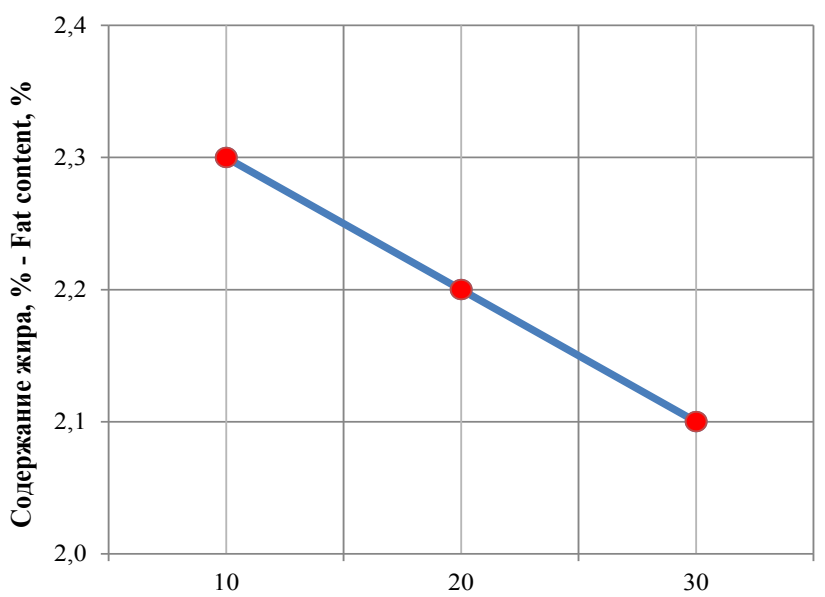

Процент замены мясного сырья свиным животным белком - percent of replacement of meat raw material with pork protein - Расчетное значение - Calculated value

- Экспериментальное значение - experimental value

Контрольный образец 1 говядина жилованная высшего copтa - Control sample 1 trimmed beef of top grade

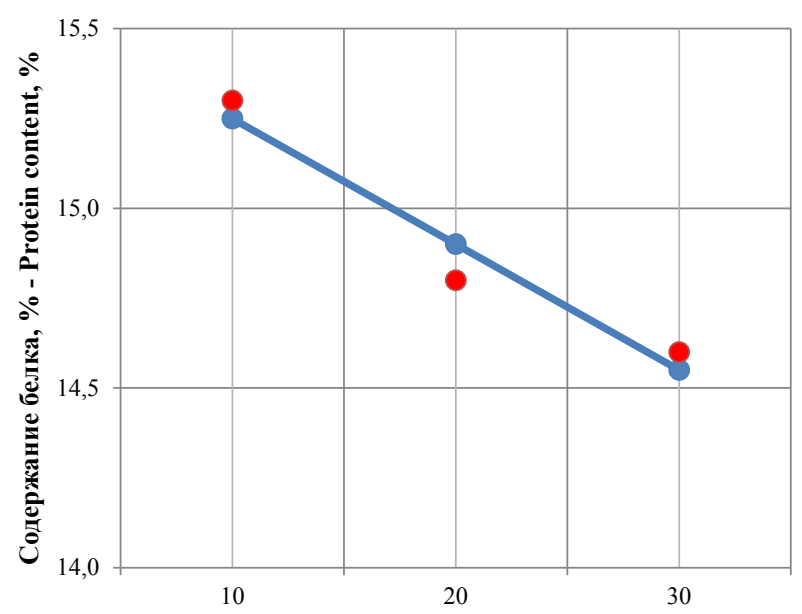

Процент замены мясного сырья свиным животным белком - percent of replacement of meat raw material with pork protein

- Расчетное значение - Calculated value

- Экспериментальное значение - experimental value

Контрольный образец 1 говядина жилованная высшего copта - Control sample 1 trimmed beef of top grade

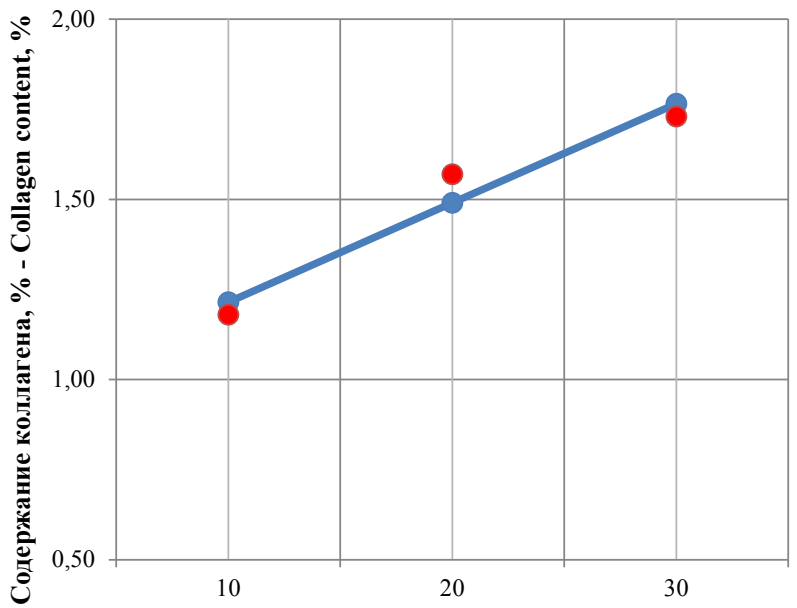

Процент замены мясного сырья свиным животным белком - percent of replacement of meat raw material with pork protein

- - Расчетное значение - Calculated value

- Экспериментальное значение - experimental value
Контрольный образец 1 говядина жилованная высшего copтa - Control sample 1 trimmed beef of top grade

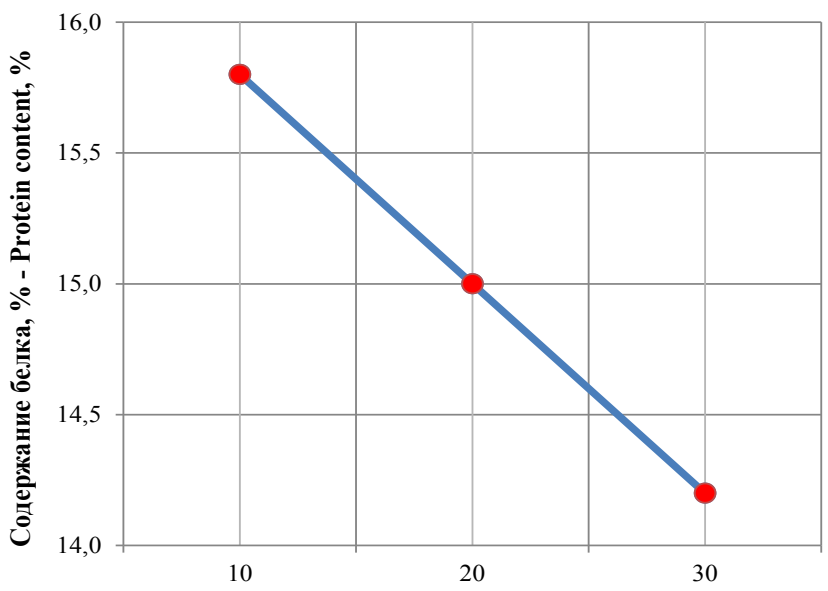

Процент замены мясного сырья говяжьим животным белком - percent of replacement of meat raw material with beef protein

- Расчетное значение - Calculated value

- Экспериментальное значение - experimental value

Контрольный образец 1 говядина жилованная высшего copта - Control sample 1 trimmed beef of top grade

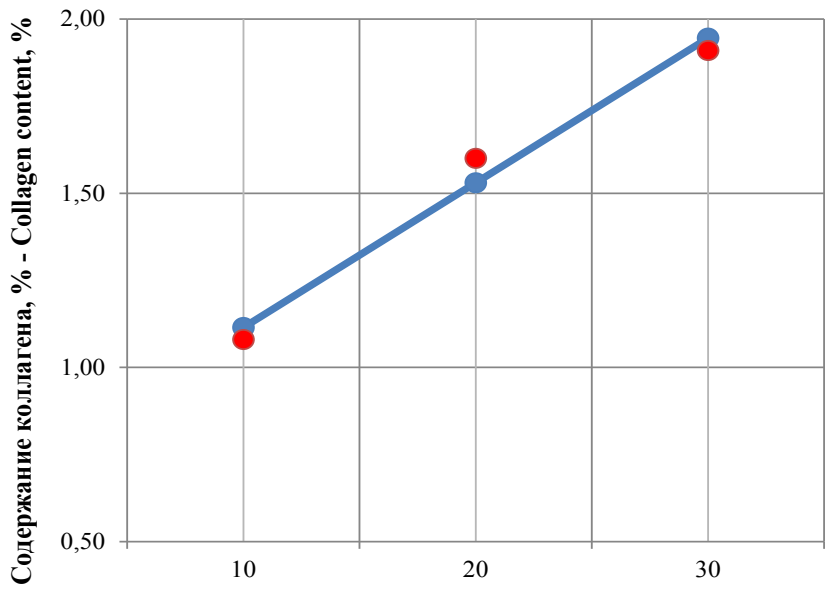

Процент замены мясного сырья говяжьим животным белком - percent of replacement of meat raw material with pork protein - Расчетное значение - Calculated value

- Экспериментальное значение - experimental value

Fig.3. Comparison of the experimental and calculated indicators Рис.3. Сопоставление экспериментальных и расчетных показателей 
Таким образом, в ходе исследований изучено влияние животных белков (говяжьих и свиных) на физико-химические и функционально-технологические показатели мясного фарша, получены стохастические зависимости с помощью методов математического и статистического анализа, а также определены максимально допустимые пределы замены мясного сырья. Сформирован банк математических моделей, позволяющий прогнозировать качество мясных изделий с учетом характеристик исходного сырья и процента замены белками животных (говяжьих и свиных).

\section{Выводы}

Применение стратегии системного анализа технологических процессов открывает широкие возможности в решении задач прогнозирования свойств, явлений, процессов и систем, их оптимизации и управления, нахождения новых эффективных технических решений в условиях, когда применение традиционных методов встречает непреодолимые трудности.

Анализ современного рынка отметил недостаточную насыщенность программного обеспечения для прогнозирования сложных многокомпонентных систем с учетом совокупности физико-химических, функционально-технологических показателей и структурно-механических свойств.

По мнению авторов, именно расширение возможностей оптимизационных программных средств позволит выйти на качественно новый уровень в разработке пищевых продуктов с заданным химическим составом, функционально-технологическими свойствами и потребительскими характеристиками.

\section{Благодарность}

Авторы считают приятным долгом выразить благодарность д.т.н., проф. Чернухе И.М. за обсуждение и критические замечания, способствующие улучшению статьи.
Thus, during the research, the influence of animal proteins (beef and pork) on the physico-chemical and functional-technological indicators of minced meat were studied, the stochastic dependencies were obtained using the methods of the mathematical and statistical analysis, and the maximum allowable levels of meat raw material replacement with animal proteins were established. A bank of the mathematical models was formed, which enables predicting meat product quality with consideration for the characteristics of the initial raw material and a percent of replacement with animal proteins (beef and pork).

\section{Conclusion}

The use of the strategy of the systemic analysis of the technological processes opens wide possibilities in solving the tasks of prediction of properties, phenomena, processes and systems, their optimization and management, finding out new effective technical solutions in the conditions when the use of the traditional methods faces unconquerable difficulties.

An analysis of the modern market revealed insufficient saturation with the software for predicting complex multicomponent systems with consideration for a set of physico-chemical and functional-technological indicators, as well as structural-mechanical properties.

In the authors' opinion, it broadens options for the software optimization that will allow us to achieve a totally new level in the development of food products with specified chemical compositions, functional-technological properties and consumer characteristics.

\section{Acknowledgement}

The authors thank doctor of technical sciences, prof. Irina M. Chernukha for discussion and critical comments that led to an improvement of the article. 


\section{БЛБЛИОГРАФЛЧЕСКИЙ СПЛСОК}

1. Кафаров, В.В. Системный анализ процессов химической технологии. // В.В. Кафаров, И.Н. Аорохов, Э.М. Колцова - М. Наука, 1988. - 367 с. (119-208)

2. Ивашкин,Ю.А.Решениенекоторыхзадачпомоделированию и оптимизации в биотехнологии // Ю.А. Ивашкин, А.В. Бородин / Теоретические основы химической промышленности. 1996. - T.30, № 4. - c. 440-446.

3. Ивашкин, Ю.А. Моделирование производственных процессов в мясной и молочной промышленности // Ю.А. Ивашкин, И.И. Протопопов, А.В. Бородин - М.: Агропромиздат. - 1987. - 256 c.

4. Косой, ВА. Инженерная реология в производстве колбас // В.А. Косой, А.А. Малышев, С.Б. ЮАина - М.: КолосС, 2005. - 264 с. 5. Горбатов, А.В. Реология мясных и молочных продуктов // А.В. Горбатов - М.: Пищевая промышленность, 1979. - 383 с. 6. Жаринов, А.И. Проектирование комбинированных продуктов питания // А.И. Жаринов, Ю.А. Ивашкин / Все о мясе. - 2004. - № 2. - с. 16-21.

7. Жаринов, А.И. Проектирование комбинированных продуктов питания // А.И. Жаринов, Ю.А. Ивашкин / Все о мясе. - 2004. - № 3. - с. 6-15.

8. Иисин, П.А. Компьютерные технологии в рецептурах расчетах молочных продуктов / П.А. Аисин. - М.: АеАи принт, 2007. - 102 c.

9. Сатина, О.В. Информационные технологии проектирования продуктов геронтологического питания // О.В. Сатина, С.Б. Юдина / Мясная индустрия. - 2010, № 6. - с. 56-58.

10. Муратова, Е.И. Автоматизированное проектирование сложных многокомпонентных продуктов питания : учеб. пособие // Е.И. Муратова, С.Г. Толстых, С.И. Аворецкий и Ар. Тамбов: ТГТУ, 2011. - 80 c.

11.Борисенко, А.А. Алгоритмы и комплекс программ Аля разработки рецептур и оценки качества нутриентной сбалансированности поликомпонентных пищевых продуктов: автореф. дисс. ... канд.техн.наук/ А.А. Борисенко - Ставрополь 2006. - 24 c

12. Бессонова, А.И. Теория и практика управления качеством пищевых продуктов на основе системы прослеживаемости : автореф. Аисс. ... Аокт.техн.наук / А.И. Бессонова - М., 2009. - 58 с. 13.Краснов, А.Е. Информационные технологии пищевых производств в условиях неопределенности // А.Е. Краснов, О.Н. Красуля О.В.Большаков и Ар. - М.: ВНИИМП, 2001. - 496 c. (329-392)

14. Николаева, С.В. Системный анализ многокомпонентных пищевых объектов и технологий в условиях информационной неопределенности : автореф. Аисс. ... Аокт.техн.наук / С.В. Николаева - М., 2013. - 56 с.

15. Kostenko, Yu.G. System of safety security and increase in efficiency of meat products manufacture using computer technologies // Yu.G. Kostenko, G.I. Solodovnikova, I.I. Protopopov et al / int. congress of meat science technology (49, 2003, Brazil), Campinas. P. 325-326.

16. Аавыдов, А.А. Имитационное моделирование Аинамики взаимодействия популяций микроорганизмов в технологиях производства сырокопченых колбас : автореф. Аисс. ... канд. техн. наук / А.А. Аавыдов. - М., 2004. - 24 с.

17. Фомушкин, В.И. Компьютерное прогнозирование рисков контаминации популяциями микроорганизмов мясного сырья в процессе хранения // В.И. Фомушкин, А.В. Бородин, И.Г. Благовещенский и Ар. / Хранение и переработка сельхозсырья - 2015. - № 7. - с. 12-16.

18. Бородин, А.В. Управление качеством и безопасностью ферментированных мясопродуктов в процессе изготовления // А.В. Бородин / Мясные технологии. - 2015. - № 12. - с. 54-56.

19. Ishikawa Karoru, Ishikawa Kaoru, Lu David J. What is Total Quality Control? The Japanese Way - Prentice Hall, 1988. - 240 p. 20. Ishikawa Kaoru Guide to Quality Control (Industrial engineering \& technology). - Quality Resources, 1986. - 226 p.

21. Клячкин, В.Н. Статистические методы в управлении качеством: компьютерные технологии // В.Н. Киячкин. - М.: Финансы и статистика, 2007. - 304 с.

22. Горбатов, В.М. Повышение функциональных свойств колбас путем оптимизации их рецептуры // В.М. Горбатов Р.М. Салаватулина, Г.П. Горошко, В.И. Мюбченко / Мясная индустрия СССР. - 1984. - № 12 - с. 20-21

\section{REFERENCES}

1. Kafarov, V.V. Systemic analysis of the processes of the chemical technology. // V.V.Kafarov, I.N. Dorokhov, E.M. Koltseva - M Nauka, 1988. - 367 pages $(119-208)$

2. Ivashkin, Yu. A. Solution of several tasks on modeling and optimization in biotechnology // Yu.A. Ivashkin, A.V. Borodin/ Theoretical basis of the chemical industry. - 1996. - Vol.30, No. 4. - pp. 440-446.

3. Ivashkin, Yu. A. Modeling of the production processes in meat and dairy industry // Yu.A. Ivashkin, I.I. Protopopov, A.V. BorodinM.: Agropromizdat. - 1987. - 256 pages.

4. Kosoi, V.D. Engineering rheology in sausage production // V.D. Kosoi, A.D. Malyshev, S.B. Yudina - M.: KolosS, 2005. - 264 pages

5. Gorbatov, A.V. Rheology of meat and dairy products // A.V. Gorbatov- M.:Food industry, 1979. - 383 pages.

6. Zharinov, A.I. Design of combined food products // A.I. Zharinov, Yu.A. Ivashkin / All about meat. - 2004. - No. 2. - pp. 16-21

7. Zharinov, A.I. Design of combined food products // A.I. Zharinov, Yu.A. Ivashkin / All about meat. - 2004. - No. 3. - pages 6-15.

8. Lisin, P.A. Computer technologies in the recipe calculations of dairy products / P.A. Lisin - M.: DeLi Print, 2007. - 102 pages 9. Satina, O.V. Information technologies of designing products of gerontological nutrition // O.V. Satina, S.B. Udina / Meat Industry. - 2010, No. 6. - pp. 56-58.

10. Muratova, E.I. Automated design of complex multicomponent food products: textbook // E.I. Muratova, S.G. Tolstykh, S.I. Dvoretsky et al. - Tambov: TGTU, 2011. - 80 pages.

11. Borisenko, A.A. Algorithms and a complex of programs for development of recipes and quality assessment of nutrient balance of polycomponent food products: author's abstract of the dissertation for a degree of the candidate of technical sciences / A.A. Borisenko- Stavropol, 2006. - 24 pages.

12. Bessonova, L.I. Theory and practice of food quality management on the basis of the traceability system: author's abstract of the dissertation for a degree of the doctor of technical sciences/ L.I. Bessonova- M., 2009. - 58 pages.

13. Krasnov, A.E. Information technologies of food productions in the conditions of uncertainty // A.E. Krasnov, O.N. Krasulya, O.V.Bolshakov et al. - M.: VNIIMP, 2001. - 496 pages (329-392) 14. Nikolaeva, S.V. Systemic analysis of the multicomponent food objects and technologies in the conditions of the informational uncertainty: author's abstract of the dissertation for a degree of the doctor of technical sciences / S.V. Nikolaeva- M., 2013. - 56 pages.

15. Kostenko, Yu.G. System of safety and increase in efficiency of meat products manufacture using computer technologies // Yu.G. Kostenko, G.I. Solodovnikova, I.I. Protopopov et al. / 49th International Congress of Meat Science and Technology (2003, Brazil), Campinas. pp. 325-326.

16. Davidov, A.A. Simulation modeling of interaction dynamics of microorganism populations in the technologies of uncooked smoked sausage production: author's abstract of the dissertation for a degree of the candidate of technical sciences // A.A. Davidov- M., 2004. - 24 pages

17. Fomushkin, V.I. Computer Prediction of Risks of Contamination of Populations of Microorganisms During Storage of Raw Meat// V.I. Fomushkin, A.V. Borodin, I.G. Blagoveshensky et al. / Storage and processing of farm products - 2015. - No. 7. - pp. 12-16.

18. Borodin, A.V. Quality and safety management of fermented meat products during production // A.V. Borodin, / Meat technologies. - 2015. - No.12. - pp. 54-56.

19. Ishikawa Karoru, Ishikawa Kaoru, Lu David J. What is Total Quality Control? The Japanese Way - Prentice Hall, 1988. - 240 p. 20. Ishikawa Kaoru Guide to Quality Control (Industrial engineering \& technology). - Quality Resources, 1986. - 226 p.

21. Klyachkin, V.N. Statistical methods in quality management: computer technologies// V.N. Klyachkin. - M.: Finances and statistics, 2007. - 304 pages.

22. 22. Gorbatov, V.M. Increasing the functional properties of sausages by optimization of their recipe// V.M. Gorbatov, R.M. Salavatulina, G.P. Goroshko. V.I. Lubchenko/ Meat industry of the USSR. - 1984. - No. 12. - pp. 20-21 


\section{СВЕДЕНИЯ ОБ АВТОРАХ}

Принадлежность к организации

Лисицын Андрей Борисович - академик РАН, доктор технических наук, профессор, ДиректорФГБНУ «Всероссийский научно-исследовательский институт мясной промышленности имени В.М. Горбатова», 109316, г. Москва, ул. Талалихина, 26. Тел.: +7(495)676-95-11e-mail: info@vniimp.ru

Никитина Марина Александровна - кандидат технических наук, доцент, ведущий научный сотрудник, руководитель направления Информационные технологии Центра «Экономико-аналитические исследования и информационные технологии» ФГБНУ «Всероссийскийнаучно-исследовательский институт мясной промышленности имени В.М. Горбатова», 109316, г. Москва, ул. Талалихина, 26.

Тел.: +7(495)676-92-14 e-mail: nikitinama@vniimp.ru

Захаров Александр Николаевич - кандидат технических наук, старший научный сотрудник, Заместитель директора по экономическим связям и маркетингу ФГБНУ «Всероссийский научно-исследовательский институт мясной промышленности имени В.М. Горбатова», 109316, г. Москва, ул. Талалихина, 26. Тел.: +7(495)676-66-91 e-mail: azakharov@vniimp.ru

Сусь Егор Борисович - кандидат технических наук, Руководитель Центра «Экономико-аналитические исследования и информационные технологии» ФГБНУ «Всероссийский научно-исследовательский институт мясной промышленности имени В.М. Горбатова»,

109316, г. Москва, ул. Талалихина, 26.

Тел.: +7(495)676-74-31 e-mail: suseb@vniimp.ru

Насонова Виктория Викторовна - кандидат технических наук, ведущий научный сотрудник, руководитель направления Технологии колбас, полуфабрикатов и упаковки Отдела «Научно-прикладных и технологических разработок» ФГБНУ «Всероссийский научно-исследовательский институт мясной промышленности имени В.М. Горбатова»,

109316, г. Москва, ул. Талалихина, 26.

Тел.: +7(495)676-61-61 e-mail: vvnasonova@gmail.com

Лебедева Людмила Ивановна - кандидат технических наук, ведущий научный сотрудник направления Технологии колбас, полуфабрикатов и упаковки Отдела «Научно-прикладных и технологических разработок» ФГБНУ «Всероссийский научно-исследовательский институт мясной промышленности имени В.М. Горбатова», 109316, г. Москва, ул. Талалихина, 26. Тел.: +7(495)676-73-61

e-mail: ludalebedeva52@bk.ru

\section{Критерии авторства}

Ответственность за работу и предоставленные сведения несут все авторы. Все авторы в равной степени участвовали в этой работе.

Конфликт интересов

Авторы заявляют об отсутствии конфликта интересов

Поступила 25.02.2016

\section{INFORMATION ABOUT AUTHORS}

\section{Affiliation}

Lisitsyn Andrey Borisovich - doctor of technical sciences, professor, academician of the Russian Academy of Sciences, Director of FGBNU The V.M. Gorbatov All-Russian Meat Research Institute, 109316, Moscow, Talalikhina str., 26

Ph.: +7 (495) 676-95-11 e-mail: info@vniimp.ru

Nikitina Marina Aleksandrovna - candidate of technical sciences, docent, leading scientific worker, the Head of the Direction of Information Technologies of the Center of Economic and Analytical Research and Information Technologies of FGBNU The V.M. Gorbatov All-Russian Meat Research Institute,

109316, Moscow, Talalikhina str., 26

Ph.: +7(495)676-92-14

e-mail: nikitinama@vniimp.ru

Zakharov Aleksandr Nikolaevich - candidate of technical sciences, senior scientific worker, Deputy Director for Economic Relations and Marketing of FGBNU The V.M. Gorbatov All-Russian Meat Research Institute, 109316, Moscow, Talalikhina str., 26

Ph.: +7(495)676-66-91

e-mail: azakharov@vniimp.ru

Sus Egor Borisovich, candidate of technical sciences, the Head of the Center of Economic and Analytical Research and Information Technologies of FGBNU The V.M. Gorbatov All-Russian Meat Research Institute,

109316, Moscow, Talalikhina str., 26

Ph.: +7(495)676-74-31

e-mail: suseb@vniimp.ru

Nasonova Victoria Victorovna - candidate of technical sciences, leading scientific worker, the Head of the Direction of Technology of Sausage Products, Semi-Finished Products and Packaging of the Department of Scientific Applied and Technological Developments of the FGBNU The V.M. Gorbatov All-Russian Meat Research Institute, 109316, Moscow, Talalikhina str., 26 Ph.: +7(495)676-61-61 e-mail: vvnasonova@gmail.com

Lebedeva Lyudmila Ivanovna - candidate of technical sciences, leading scientific worker of the Direction of Technology of Sausage Products, Semi-Finished Products and Packaging of the Department of Scientific Applied and Technological Developments of FGBNU The V.M. Gorbatov All-Russian Meat Research Institute,

109316, Moscow, Talalikhina str., 26

Ph.: +7(495)676-73-61

e-mail: ludalebedeva52@bk.ru

\section{Contribution}

All authors are responsible for the work and presented information. Authors have made an equal contribution to this work

\section{Conflict of interest}

The authors declare no conflict of interest

Received 25.02.2016 